\title{
Project-Based Learning as a catalyst for Students and Teacher Autonomy Development: The experience in a State School in Nilo, Cundinamarca.
}

\author{
El Aprendizaje Basados En Proyectos como catalizador \\ del desarrollo de la Autonomía en los Estudiantes y el \\ Profesor: La Experiencia vivida en un Colegio Oficial en \\ Nilo, Cundinamarca.
}

\author{
Jose Fabián Agudelo and Adriana María Morales-Vasco2* \\ IED Oreste Sindici and Universidad del Tolima, Colombia
}

\begin{abstract}
This paper reports the findings of a graduation thesis which intended to identify the effects that Project-Based Learning implementation had on the development of autonomy of a group of tenth grade English language learners and their teacher. In this Action Research study, several instruments were used. An initial questionnaire to confirm perceptions; a student's attitude scale to assess how students worked, both individually and in small groups; small group conferencing, which enabled students to speak about their projects; a teacher-research journal with teacher's reflections on the implementation and effectiveness of the action strategies; and students' journals containing reflections on the different stages of the process. The data gathered showed that PBL work led to both learners and their teacher having more positive attitudes and behaviors towards their own academic activities and teaching practice, respectively. This methodology encouraged learners to become decision makers, to gain responsibility and confidence, and to raise awareness of their role in the classroom, while also promoting the development of several features of the teacher's teaching style. Thus, knowledge in the classroom was built cooperatively.
\end{abstract}

Key words: Autonomous learning; teacher's autonomy; awareness; decision makers; missions; Project Based Learning; students' attitude; responsibility; confidence; collaborative work.

1 Received: April 18th 2018/ Accepted: July 21 2019

2 teachfab@gmail.com; ariadna38@gmail.com 


\section{Resumen}

El presente trabajo da cuenta de los hallazgos surgidos de una Investigación Acción como proyecto de grado, cuyo objetivo era identificar los efectos de la implementación del modelo de trabajo por proyectos sobre el desarrollo de la autonomía de un grupo de estudiantes de inglés de grado décimo y su profesor. Para tal efecto se utilizaron instrumentos como: un cuestionario de inicio, para confirmar percepciones previas; una escala actitudinal para medir el trabajo individual y grupal de los estudiantes; conferencias en pequeños grupos, para analizar el trabajo de los estudiantes en los diferentes proyectos; el diario del profesor, que contenía las reflexiones después de la observación del trabajo de los estudiantes y; el diario de los estudiantes, donde éstos consignaron sus impresiones después de cada proyecto desarrollado. El análisis de la información colectada arrojó evidencias claras sobre el desarrollo de actitudes y comportamientos positivos de los estudiantes participantes y el profesor-investigador frente a sus actividades académicas y su práctica pedagógica, respectivamente. Los proyectos implementados alentaron a los aprendices en la toma autónoma de decisiones y en el acrecentamiento de su responsabilidad y su confianza. Asimismo, los estudiantes, a través de su trabajo, exhortaron al profesor a mejorar su práctica pedagógica. En consecuencia, la construcción del conocimiento se convirtió en una labor hombro a hombro.

Palabras clave: Aprendizaje autónomo; profesor autónomo; actitud de los estudiantes; conciencia; toma de decisiones; misiones; trabajo por proyectos; responsabilidad; confianza; trabajo colaborativo.

\section{Resumo}

O presente trabalho da conta das descobertas surgidos de uma Pesquisa Ação como projeto de formatura, cujo objetivo era identificar os efeitos da implementação do modelo de trabalho por projetos sobre o desenvolvimento da autonomia de um grupo de estudantes de inglês de segundo ano do ensino médio e seu professor. Para tal efeito se utilizaram instrumentos como: um questionário de inicio, para confirmar percepções prévias; uma escala atitudinal para medir o trabalho individual e grupal dos estudantes; conferências em pequenos grupos, para analisar o trabalho dos estudantes nos diferentes projetos; o diário do professor, que continha as reflexões depois da observação do trabalho dos estudantes e o diário dos estudantes, onde eles consignaram suas impressões depois de cada projeto desenvolvido. A análise da informação coletada evidenciou evidências claras sobre o desenvolvimento de atitudes e comportamentos positivos dos estudantes participantes e o professor-pesquisador diante de suas atividades acadêmicas e a sua prática pedagógica, respectivamente. Os projetos implementados animaram os aprendizes na tomada autônoma de decisões e no acrescentamento da sua responsabilidade e sua confiança. Da mesma forma, os estudantes, através do seu trabalho, exortaram o professor a melhorar a sua prática pedagógica. Em consequência, a construção do conhecimento converteu-se em um trabalho ombro a ombro.

Palavras chave: Aprendizagem autônoma; professor autônomo; atitude dos estudantes; consciência; tomada de decisões; missões; trabalho por projetos; responsabilidade; confiança; trabalho colaborativo. 


\section{Introduction}

7 he increasing importance of English in Colombia has promoted not only new policies on English teaching but challenged the educational system and its participants to devise strategies to educate learners to achieve a certain level of proficiency in this language. However, teachers struggle with a diverse array of difficulties, including learners' inabilities to develop interest in and motivation towards the study of a foreign language, coupled with a lack of self-confidence to understand and use such languages. The battle to fully engage students, who are often inattentive or easily distracted, in the learning activities, and the apparent lack of commitment to complete work outside the classroom are on top of the those that teacher's face in every subject. As a result, this research study was designed to investigate possible teaching strategies that may overcome these barriers mentioned above that are hindering English proficiency across schools in Colombia. Following an analysis of the concept of autonomous learning, a more conscious perspective emerged: the two actors in the classroom, teacher and student, inevitably depend upon each other. Through the Project, students were given the opportunity to have a more active involvement and be more aware of their role in their own learning process. Concurrently, the purpose was to encourage teacher(s) to identify strategies to improve their own teaching practice. The procedures explained below demonstrate attitudinal and practical changes in both the learners and the teacher.

\section{Literature Review}

The concept of Project-Based Learning (PBL) is related to the constructivism principles that emerge from the pragmatic, cognitive, and social constructivism view evidenced in Dewey's philosophy (Railsback, 2002). Considering this, PBL recognizes aspects not only in regards to the nature of learning but its application to real life, and the possibility of improving learning by making it into an active process, with interacting and involvement of the surrounding environment. Hence, through PBL students should be able to apply what they learn to everyday life scenarios and understand the possibility to improve by working with others. Furthermore, it encourages students to be more engaged, due to the more challenging and complex nature of the work, and the interdisciplinary rather than a departmentalized focus (Anderman \& Midgley, 1998; Lumsden, 1994 in Railsback, 2002). For this reason, the interaction between teacher, learner, and environment must be boosted.

PBL enhances students' motivation and increases responsibility in the learning process. As Fried-Booth (2002) states: "Project Work offers learners an opportunity to take a certain responsibility for their own learning, 
encouraging them to set their own objectives in terms of what they wanted and needed to learn." (pg. 6) Building on from this, Stoller (2002), in a more detailed description, highlighted the importance of student focused approach: negotiation of students' interests; attention to topics and content that students are interested in; student-centered instruction; integration of the four skills in lesson activities; preparation and presentation of a final product; and promotion of students' autonomy in the learning process. Therefore, it is important that the different stages of PBL can be developed and adapted according to the needs and requirements of the individual teachers and their students in diverse teaching and learning contexts.

Learner autonomy is seen as a key feature to promote learners' awareness of the skills, learning styles, strategies and attitudes that influence their learning. For this reason, the concept of learner autonomy and its literature requires exploration.

Despite its importance, the concept of Learner Autonomy is difficult to define precisely (Little, 2000). In fact, the discussion is still open as to whether it is considered a capacity or a behavior, with Little (1991) defining Autonomy as "a capacity - for detachment, critical reflection, decision-making, and independence" (p.4), while Holec (1981) states that learner autonomy is the ability to take charge of one's own learning. Furthermore, the interpretation of learner autonomy can differ from culture to culture and person to person due to differences in belief systems and perspectives. On their part, Benson \& Voller's (1997) idea is that autonomy is subject to the abilities and attitudes that people possess and, as a result, it can be developed in different ways to varying degrees.

The literature on learning autonomy includes a wide range of contexts such as holistic, social, political, and even philosophical. Benson (2007) suggests that the concept of autonomy can be applied to three distinct contexts, with a different definition in each; technical, political, and psychological. At the technical level, autonomy is concerned with the management, strategies, and techniques of learning, whereas at the political level, it is the ability to control the situational contexts of learning. And lastly, at the psychological level, the author defines autonomy as the inner capacity for self-direction or self-regulation of learning.

34 In the same vein, Nunan (1997) claims that encouraging learners to move towards autonomy is best done inside the classroom, by incorporating student focused content goals and learning processes. In order to achieve this, it is necessary to involve them in making choices and creating situations in which they are able to develop their own goals and learning strategies, From the Literature on autonomy, the main features of the term that are repeatedly used, highlight the responsibility of a person to analyze the various possibilities in a 
situation, make informed and considered choices, and effect changes in one's life and activities.

\section{Teacher's role}

Teachers play a key role in promoting students' autonomy; however, they must develop their own autonomy before being able to help learners with theirs. For some authors, Teacher Autonomy refers to "the teacher's ability and willingness to help learners take responsibility for their own learning" (Thavenius, in Cotterall \& Crabbe,1999). According to this definition, teachers must reflect on their role and develop ways to adapt to the students' new roles, in order to help them on their way to becoming autonomous and independent. There is a clear link between learner and teacher autonomy, although greater emphasis is placed on the former because it requires the latter to achieve it. To widen the concept of teacher autonomy, Little (1995) explains that for teachers to be autonomous, they must develop a strong sense of personal responsibility for their teaching, through continuous reflection and analysis of their teaching, and affective and cognitive control of the teaching process. Supporting this idea, Tort-Moloney (1997) refers to an autonomous teacher as "one who is aware of why, when, where, and how pedagogical skills can be acquired in the self-conscious awareness of teaching practice itself."(p. 51) In addition, Little (as cited in Smith, 2001) established the connection between teacher and student autonomy when he remarked that "it is unreasonable to expect teachers to foster the growth of autonomy in their learners if they themselves do not know what it is to be an autonomous learner." As a result, teachers may also need to address their own beliefs about teaching and the perspectives of learner autonomy. If not, as Lamb and Reinders (2008) claim, the teacher could, intentionally or unintentionally, constrain learner autonomy in the classroom leading to a lack of authenticity in learning.

\section{Methodology}

This study followed a qualitative approach and was based on the principles of descriptive Action Research Methodology. Burns (2010), Jhonson (2008), and Allen and Calhoun (1998) claim that Action Research provides educators an opportunity to reflect on their own practice and seek to identify and investigate problems in their own classrooms.

\section{Problem statement}

The initial concern for the teacher in the English language classroom was that the participants in this study were habitually inattentive, got easily 
distracted, and frequently complained about the activities proposed by the teacher(s). Students often expressed that they did not know enough English to be able to cope with the activities, and they were not confident enough to use the foreign language in class. Through teachers' meetings, the teacher-researcher realized that those attitudes and behaviors expressed by the students, were quite similar across subjects; with teachers from other disciplines referring to those particular students as "reckless, lazy, undisciplined, unpunctual, uncommitted, and unconscious of their life projects." Teachers believed the characteristics listed above showed a profound lack of autonomy in learners, and hence learning autonomy became the focus of this study.

\section{Research Questions}

Consequently, the question to be answered in this study was: What happens to students' autonomy and the teacher's self-development in our tenth-grade classroom when we implement Project Work for the first time?

\section{Sub Questions}

- The question above was supported by the ones below:

- What are the perceptions of students and teacher in regards to the implementation of Project-Based Learning in the classroom?

- What changes are revealed in the students' autonomy after they get involved in Project Based Learning?

- What changes are evident in the teacher's development following the implementation of Project- Based Learning?

\section{Context and Participants}

This action research project was carried out in a 10th grade EFL cl ass, at a state primary and secondary school in Nilo (Cundinamarca, Colombia), during four 55-minute classes. English instruction was focused on the development of the four language skills. The participants in this study were the teacher-researcher and 21 tenth grade students, 11 boys and 10 girls, whose native language is Spanish. Their ages ranged between 14 and 18 years old. Almost $50 \%$ of them lived in a rural community, and thus many lacked the resources for extra practice, such as libraries or computers, with very few having access to the internet. As they were all beginners, they had particular difficulty expressing their ideas by speaking or writing; however, they could read basic texts and understand elementary instructions given by the teacher. 
Each of the projects or "Missions", as called by the teacher-researcher, comprised four aspects: planning, implementation, presentation of product, and Evaluation.

For the planning step, students shared their ideas about project topics, preferred methodology, resources, and evaluation procedures. The teacher collected all those ideas and opinions with no exception. Regarding topics, 10th graders preferences focused on music, sports and fashion; they also showed predilection for culture, interviews, and gastronomy. After this preliminary exploration of interests and preferences, the teacher asked pupils to gather in groups (which were assigned according to students' choices). Thus, the teacher summarized information and encouraged learners to discuss and decide on plausible Projects to be implemented in the English class.

After small group discussions, the teacher asked the class to gather in groups, and they were assigned these projects: "A Fashion show", "around the world (Knowing different cultures and countries)", "interviewing a guest on T.V News", "School news", and "teaching others."

Teacher's recommendation for his tenth graders was to develop their first Project by describing school to make it visible to the community. To accomplish this mission, students practiced the vocabulary, expressions, and grammar structures learnt during previous classes. Teacher wanted his learners to be able to use language, so he encouraged them to tell the world about the place where they study through a video.

Mission: "To post a Video presenting the place where I study and receive comments in English."

Considering students' previous decision, the teacher suggested a new project through which learners could develop topics they were interested in. "School news" seemed to collect not only topics of their preferences but helped to develop languages abilities proposed by the syllabus at the time it allowed pupils to learn by doing cooperatively. Thus, learners could practice English by telling news considering different topics such as: national, international, sports, fashion, local, school, and environmental news.

To develop this project, tenth graders were encouraged to search information by reading newspapers, watching news, or expanding ideas form classes different from English. Students' first mission consisted on becoming updated in global facts, knowing about the community and the school. Likewise, Spanish, social sciences and English teachers helped students to expand and support that information. In order to develop this project and collect information, students learnt to ask questions, do interviews, report, read articles, do chronicles, and create into the classroom an environment for the news format together with the teacher. Among their tasks, they interviewed, 
and video recorded teachers at school, students, local people and candidates for Nilo's town hall.

\section{Data gathering instruments and techniques}

For data collection, various methods were considered. Firstly, a questionnaire was used to confirm the teacher-researcher's perception of the lack of interest in learners for their learning, then, a student's attitude scale which gave the researcher a clear idea of the students' perceptions of how they themselves worked, both individually and in small groups. Furthermore, small group conferencing (Johnson, 2008) was implemented with students in class, which enabled them to speak informally and spontaneously about their projects. Finally, a teacher-researcher journal with teacher's reflections on the implementation and effectiveness of the action strategies; and the students' journals containing reflections on the different stages of the process (Burns, 2010).

\section{Data Analysis and Outcomes}

The data was scrutinized following the principles of Content Analysis, since it is a method that may be used with either qualitative or quantitative data, in an inductive or deductive way. The categories were derived from the data, and thus it took the form of an inductive content analysis (Kynga"s \& Vanhanen, 1999). The results show what happens when PBL is implemented in the classroom for the first time, and how it can be related to the development of autonomy.

After analyzing the information gathered through the different instruments, students and teacher expressed their thoughts and feelings about the activities done in class.

\section{Students' Voices}

Responsibility. This is the aspect that most students recognized as a positive outcome after implementing PBL. Thus, it was evidenced that this methodology contributed to the development of both individual and collective responsibility, helping the initial features of increased self-management, power and control, leading to the development of autonomy, punctuality, and commitment.

Besides the features above, learners were concerned about the concept of quality. They became aware of the importance of making things better and realized that PBL stages positively influenced some aspects of their attitudes 
including their decisions, performance, motivation, and consequently, their learning. In order to illustrate the five aspects referred to above, we will quote some excerpts taken from the students' journals.

"Con estos proyectos somos más puntuales, responsables porque se convierte en una obligación entregar las actividades, no porque sea impuesto por el profesor sino porque fue algo a lo que yo me comprometí y mis compañeros también." (N.F.) ["With these projects we are more punctual and responsible because it becomes an obligation to present the activities. It is not an imposition from the teacher, but my partners' and my personal commitment."']

Increasing motivation. During the implementation of PBL, learners described how motivation positively influenced their accomplishment of the objectives and their performance in the English class. Thus, intrinsic and extrinsic motivations were evident. Some students felt the inner desire to complete their goals because they wanted to perform well and to improve in each presentation they did. Likewise, extrinsic motivation came from the implicit commitment to accomplish the activities not only for themselves but also for the other members of the group, including the teacher.

At the beginning of the implementation, students showed interest because it was the first time they faced challenging activities. The work increased the learner's motivation to assume a new methodology, a new way to work in class, and a disposition towards learning. After some of the missions were achieved (expression used by the teacher to increase motivation and describe the activities), learners were expected to improve on subsequent missions. The idea to accomplish missions promoted interest in the learners and motivated them to achieve the collective goals. Nevertheless, one of the most reliable aspects that caught the students' attention and interest was demonstrated at the first stage of the implementation when the teacher made the learners part of the process, giving them a main role: recognizing how important they were when their voices were heard for the first time in the activity. Learners assumed the role of the decision makers, and together with this power to make decisions, greater motivation and a sense of commitment came. Letting the students be active participants in the projects and their learning is a great strategy to promote cooperation and strong commitment among learners, since they feel unconsciously or implicitly forced to achieve the project goals.

Another aspect that boosted student interest was the innovative proposal that consisted in practicing the language while searching and collecting information outside the classroom using different data collection instruments. Breaking the boundaries of the physical and metaphorical classroom walls allowed students to learn by practicing. Therefore, by encouraging students to 
do activities outside the classroom, a new perception of learning is promoted where they take a more active role in the process.

"Ahora que viene un nuevo proyecto estoy muy entusiasmada y estoy segura que mi nuevo proyecto va a sobresalir, fuera pereza... fuerza pereza." ["Now, that a new Project is coming, I am very excited; I am sure that my new Project will stand...Laziness, get out!']

"Me siento muy bien que el profe nos haya tenido en cuenta para la elaboración de los proyectos, quiero dar mi mejor esfuerzo." (J.M.). ["I really liked that teacher considered us for this Project; I want to do my best."]

Working with others. PBL promoted collaborative work, which is perceived as the act of two or more people working together to achieve a particular goal, either by the sharing of ideas at each stage of the process or the dividing up of the workload. Most of the 10th graders agreed on the importance of working together. The use of collaborative work was an attempt to encourage learners to share knowledge, complement strength, overcome weaknesses, gain confidence, make decisions on different ideas, distribute hard work, and most of all, gain awareness of how one's good or bad work affects others.

Students demonstrated positive skills while working together, particularly the responsibility to do their best as a team in order to accomplish the objectives proposed in every single mission. Thus, working together is a positive aspect when students discover that, in order to accomplish objectives easily, it is necessary to support and be supported by others. Throughout this project, the positive perception of collaborative work in the 10th graders continued to increase, with collaborative work enhancing the responsibility and interaction of each group member to ensure the whole group succeeded.

"Aunque todos no trabajamos al mismo ritmo, me gusta trabajar en grupo porque entre todos aportamos ideas, cumplimos con las misiones y sacamos los proyectos adelante" (D.G.) ["Although, we do not work at the same pace, I like working in groups because we all supply ideas, carry out missions and forge projects ahead."]

Getting confidence. PBL raised good feelings towards learning. Students truly perceived improvement in their learning, which was shown by better performances, more accurate use of language, and a higher quality of work. Additionally, this research demonstrated that PBL encouraged learners not only to learn English but also to improve aspects of their personal life; including the 
ability to overcome fears, gain confidence, and develop independence. This idea is supported by S.F., when he says: "Con esta nueva metodología que estamos trabajando ahora se aprende mucho más que en una clase común y corriente" ["With this new methodology, we have learnt much more than we used to do in traditional classes. "]. This idea of gaining self-confidence and self-esteem is confirmed by the students' reports of feeling more engaged towards learning English and more enthusiastic, as they are now able to do certain things that they previously could not. For instance, "Lo mejor que tiene este tipo de proyectos es que nos atrevemos y dejamos el miedo atrás, nos atrevemos a hacer cosas diferentes como ponernos frente a una cámara y perder la pena". HB. ["The best aspect of this type of Project, we dare to do different things, and leave fear behind us, like being in front of the camera and leave shame away."]

Raising awareness. Using student self-evaluation as an instrument to promote reflection was an important way to encourage learners to achieve the objectives at each stage of the projects. It helped learners to recognize, in themselves and in their work, areas of weakness and strength, areas that required more work, or areas that they were less confident in, their likes and dislikes, and even their beliefs. With the support of their classmates and the guidance from their teacher, the students were able to improve upon any areas that were hindering their performance and also take advantage of their strengths. The process of evaluation was implemented using two strategies; the use of journals to enable the students to express their opinions and feelings and, an attitude scale, where the actions of reflection emerged at the end of each mission when the teacher-researcher asked students to evaluate the performance of each member of the group. The latter activity meant students could see how others perceived their work in class and could compare how distant their self-perception and others' opinions were. This was useful, as for some students it confirmed and reinforced their good performance, and for others it encouraged them to have a greater commitment to the subsequent activities.

The last activity of the project was the final evaluation, in which the students had to complete a self-assessment and present their report to their teacher, taking into account the achieved objective and their effort to complete it. The purpose of this activity was to augment the development of the student's sense of responsibility and independence and encourage honesty. This enabled students to be active participants and made them aware of their learning process.

This self, peer, and co-evaluation generated a sense of reflection upon learners that made them conscious of their work and invited them to reflect on how far or close the achievement of the objectives was. 
Regarding this aspect, D.G. said: "No me gustó que algunos compañeros me hayan puesto mala nota, aunque me esforzaré en el próximo trabajo para demostrarles que si puedo hacer las cosas. " ["I did not like getting a bad mark from my classmates, although I will struggle next time to demonstrate to them that I can do it well'].

On her part, another student said: "siendo honesta me dio pena que mis compañeros me calificaran porque en este primer trabajo no cumpli con lo que debia hacer. Me esforzaré más" (A.C.) [ "To be honest I felt ashamed when my classmates evaluated me, because in this first activity I did not accomplish what I had to. I will do my best next time. "]

\section{Teacher's voice}

Eager teacher. Implementing PBL in 10th grade was a new challenge not only for students, for the students but for the teacher breaking the traditional teaching styles. It was the first time we had worked in such a different manner, breaking the more traditional teaching styles. Implementing methodologies that you never tried before makes you feel unconfident; it creates anxiety due to the expectation to promote acceptance in learners, also the possible changes not only in students but in teacher practice. The teacher adapted the syllabus not only considering the topics to be covered, and each of their time frames, but the pedagogical methods to be used; for this reason, the teacher designed some strategies and possible activities that matched with the features of PBL. There were two main challenges that had to be considered at the start of the process. On the one hand, the anxiety of using unfamiliar pedagogical methods that would challenge the teacher's previous teaching experience, alongside his limited research experience. On the other hand, was the dilemma of how best to implement in the classroom the different theories and concepts on learner autonomy, while managing the reaction of the students towards the new way of working, and the best way to encourage their engagement.

Time to listen. Motivation of the students was evident during the different stages of the implementation. This motivation was generated by enabling the students for the first time, to be part of the decision making, alongside the teacher, with the methodological principle focusing on the students as the main actors in the learning process. The students were very involved when their teacher asked them about their opinions to build a new class, their interests, likes, and preferences in terms of topics, strategies, and even in their evaluation method. This first stage of the project was much more democratic than more traditional teaching styles, allowing students to express their opinions and ideas and collectively make the final decision. They felt empowered by having the responsibility of suggesting the different projects to be undertaken by the class. Students moved from being just receivers to being proposers. " "In this 
early step of the process, I have evidenced that my students like to be consulted about their preferences towards the class, although they recognize they agree with some of the activities we do daily, they express they would like to try others, for instance; to work with videos or outside the classroom." However, it was quite important that students realized that although they had much more independence, they were not alone, with continuous guidance available.

School Community. Delegating to the students the responsibility of gathering information for the project allowed the teacher to identify their willingness to adopt an active role. "What a nice surprise... students are so motivated; some of them are even trying to interview candidates for Nilo's mayoralty". "They took good pictures (they must spend time outside the classroom)." "Wow... I feel good watching my students going around school with their cameras, paper, and pens asking other teachers for information." Importantly, the implementation of PBL allowed the participation of all the community, pupils, and teachers.

Reflecting as a new opportunity. This stage promoted a dialogical discourse among students themselves and with the teacher. The students' voices were again taken into account and, as the performances of both students and teacher were evaluated, meaningful changes emerged as a result; the reflection time helped the teacher to access the suitability of the pace of the projects to determine the attainment of objectives by the learners, to confirm the suitability of the methodology and the activities, and to establish a set of actions that contributed to enhance collaborative work and to reduce constraints in the process.

Building together. The teacher enjoyed taking the role of guide, facilitator, listener, motivator, and advisor when implementing projects; the teacher's voice was as relevant as the students. Although at the beginning of the project students misunderstood the role of the teacher and questioned his contributions, during the implementation of the projects, a more balanced participation of student and teacher was reached. Evidence of this is shown in the following excerpts: "I heard some of my learners complaining and saying that I need to help them more; they feel I am extremely demanding but the hard work is for them... I realize, that we need time to reflect and explain them the purpose of implementing projects in class and the challenges we need to tackle in both directions. 


\section{Conclusions}

At the beginning of this process, the tenth graders were perceived as inattentive, easily distracted, and students who would complain about any activity proposed. Furthermore, they were perceived as reckless, lazy, undisciplined, unpunctual, not committed, and unconscious of their life projects. Nevertheless, after implementing PBL, students showed some meaningful changes to their behavior and their view of learning. They became more responsible, punctual, committed, and honest. These features of autonomy that the students demonstrated indicate the starting point of a journey towards a better attitude in regards to their academic commitments. Students became more conscious and aware of their role in the classroom, recognizing that good results depend on good performance, and the former is attainable for them, if they work well. They realized that the role of the learner goes beyond the passive receiver, that they should take an active role in the learning process and recognize what is important for their further decisions. These particular students are now able to confront doubts, fears, misunderstandings, insecurity, and some features of low self-esteem. They were able to see that independence emerges when students are aware that they are in charge and take control of aspects of their personal life. However, while the students did demonstrate all the aforementioned positive attitudes during the implementation of PBL, it is not possible to determine whether these aspects of learner autonomy were continued outside of the English classroom setting, for instance during their other classes or applied to decisions outside of the school setting. Hopefully, they were.

Finally, the teacher's self-development was influenced during this study as well. Therefore, he advanced his abilities in solving doubts, dispelling misunderstandings, becoming a motivator, and in guiding his students. It also encouraged him to accommodate new ideas of a creative and innovative nature, which boosted his pedagogical skills. The teacher is now conscious of the need to move from a teacher-centered towards a student-centered model, avoiding the idea that the learners must only follow their teacher's instructions. He realized that, in order to develop autonomy in his students, it was necessary to make a mirror process for analyzing his own autonomy first, so that learning emerged in a co-creation process.

This paper may encourage teachers to get involved in self-reflection processes upon their teaching practices and their teaching styles; in the same vein, it may compel teachers to undertake methodologies that allow learners to have a more participatory role in class where students' opinions and decisions could be taken into account. Likewise, it demonstrates how studentcentered methodologies like PBL develop in learners some autonomous practices, whereby real-world connections are made. Along with them, the use of critical thinking skills, of technology, and the enhancement of creativity 
and innovation facilitate independence, responsibility, decision making and democratic participation of learners.

All in all, this research could become the starting point for new studies that attempt to explore the long-lasting effect that the implementation of PBL could have on students' attitudes toward academic work and personal life projects. 


\section{References}

Allen, L. \& Calhoun, E. (1998). Schoolwide Action Research: findings from six years of study, Phi Delta Kappan, 79(1), 706-710.

Benson, P. \& Voller, P. (1997). Autonomy and independence in Language learning. London, UK: Longman.

Benson, P. (2007). Autonomy in language teaching and learning. Language Teaching, 40(1), 21-40.

Burns, A. (2010). Collaborative Action Research for English Teachers. In K. Dikilitaş \& C. Griffiths, Developing Language Teacher Autonomy through Action Research. Switzerland:Palgrave-Macmillan.

Cotterall, S. \& Crabbe, D. (Eds.). (1999). Learner autonomy in language learning: Defining the field and effecting change. Frankfurt, Germany: Peter Lang.

Fried-Booth, D. L. (1997). Project work. (8th Ed.) Oxford: Oxford University Press.

Fried-Booth, D. L. (2002). Project work. (2nd Ed.) Oxford: Oxford University Press.

Holec, H. (1985). On Autonomy: some elementary concepts. In Riley, P. (Ed.), Discourse and Learning. London: Longman.

Jhonson, A. P. (2008). A short guide to action research, $3^{\text {rd }}$ ed. Boston, MA: Pearson.

Kyngas H. \& Vanhanen L. (1999). Content analysis. Hoitotiede Journal, 1(1), $3-12$.

Lamb, T.E. \& Reinders, H. (Eds.) (2008). Learner and teacher autonomy: concepts, realities, and responses. Amsterdam: John Benjamin.

Little, D. (1991). Autonomy: Definitions, Issues and Problems. Dublin, Ireland: Authentik.

Little, D. (1995). Learning as dialogue: the dependence of learner autonomy on teacher autonomy. System, 23(2), 175-182.

Little, D. (2000). Learner autonomy: why foreign languages should occupy a central role in the curriculum. In R.C. Smith, Teacher education for teacherlearner autonomy. Symposium for Language Teacher Educators: Papers from Three IALS Symposia (CD-ROM). Edinburgh: IALS, University of Edinburgh.

Nunan, D. (1997). Designing and adapting materials to encourage learner autonomy. Frankfurt: Peter Lang. 
Railsback, J. (2002). Project-Based Instruction: Creating Excitement for Learning. Portland, OR: Northwest Regional Educational Laboratory.

Smith, R. C. (2001). Teacher education for teacher-learner autonomy. Retrieved on November 28, 2017, from http:/homepages.warwick. ac.uk/ elsdr/Teacher_autonomy.pdf

Stoller, F. (2002). Project Work: A Means to Promote Language and Content. In J. Richards \& W.

Renandya (Eds.), Methodology in Language Teaching. An Anthology of Current Practice. Cambridge, England: Cambridge University Press.

Tort-Moloney, D. (1997). Teacher Autonomy: A Vygotskian Theoretical Framework. Dublin, Ireland: Centre for Language and Communication studies. 


\section{Authors}

*José Fabián Agudelo-Rodríguez M.A. in English didactics from Universidad del Tolima (Ibagué). Specialist in English Language teacher from Universidad de Ibague. B.A. in Modern Languages from Universidad de Cundinamarca (Girardot). English teacher with 14 years of experience working with children, teenagers and adults mainly in state schools. Currently a Full-time teacher and coordinator at state school Oreste Sindici in Nilo Ccundinamarca since 2010 to the present

ORCID: https://orcid.org/0000-0001-8489-5830

Adriana María Morales Vasco Magister in English Didactics from Universidad de Caldas (Manizales), 1998. B.A. in Modern Languages from Universidad del Quindío (Armenia), 1994. English Lecturer in the Modern Languages Program at Universidad del Quindío, 20052009. English teacher at different state and private schools working with children and teenagers, 1994-2004. Researcher in the fields of EFL Methodology, ELT, Pedagogy and Teacher Development. Speaker at numerous national and international academic events. Author and coauthor of several articles published in indexed national journals. Fulltime professor in the B.A. in English and the Master Program in English Didactics at Universidad del Tolima since 2009 to the present.

ORCID: https://orcid.org/0000-0002-4905-0186 